\title{
THE STRUCTURES OF THE EUROPEAN POULTRY INDUSTHY : THEIR TRENDS
}

\author{
J. P. SINQUIN \\ Chef de la Division Économie à l'I.T. A.V.I., \\ 28, Rue du Rocher, \\ 75008 Paris
}

Among the agricultural productions, the poultry industry has been characterized by the most important changes during the last io or I 2 years.

In some countries it is possible to follow very well the increase in the size of poultry production units owing to regular census.

As regards egg production, there are still a lot of small units with less than hundred layers (farm productions). There are only one or two thousands of units with more than 5 ooo layers in each country, but they represent from 40 to 60 p. Ioo of the total of layers.

For the broiler sector, the production is more concentrated. The units with more than Io ooo broilers represent from 68 to $95 \mathrm{p}$. Ioo of total livestock, but there are only some hundreds of these units.

Generally speaking, production is more concentrated in the United Kingdom than in other countries. It can be explained by the development of big integrated firms in U. K. In West Germany, concentration is also going very fast, but in the Netherlands and Denmark, the mean size is more modest because of the importance of cooperatives in these two last countries.

It is difficult to know what will be the optimum size in the future, it can only be said that concentration will continue.

The size of poultry units finally depends on a lot of factors which can be technical, economical and political factors.

In different countries, an attempt has been made to limit the size of the units in order to balance production with demand and to limit the effect of crisis of the prices paid to producers.

\section{EXPANSION OF LARGE POULTIIY ENTERPRISES IN THE E. C. M.}

\author{
F. NICOLAS et J.P. SINQUIN \\ I. N.R.A., I. T. A.V.I., \\ 28, Rue du Rocher, \\ 75008 Paris
}

One can estimate that the event "large enterprise " has become a major fact in European poultry business since I970. Though being mostly national, the large poultry enterprise has from now on a decisive influence upon the development of production structures and markets. 